UDC 633.1:632.9

(C) 2016

\title{
Predominant virus diseases of earstem grasses in conditions of East Forest-steppe
}

\section{Petrenkova,}

Corresponding Member of the National Academy of Sciences of Ukraine, Doctor of Agricultural Sciences

\author{
I. Luchna, \\ Candidate of Agricultural Sciences \\ Institute of Plant Science of NAAS named after V.Ya. Yurieva \\ Ye. Oleinikov \\ Kharkov National Agrarian University named after VV Dokuchaev \\ L. Mishchenko, \\ Doctor of Biological Sciences \\ Kyiv National Taras Shevchenko University
}

The purpose. To determine predominant sorts of virus diseases of earstem grasses in Forest-steppe of East Ukraine and ways of transfer of a virus. Methods. They used solid-phase enzyme immunoassay (sandwichalternative), methods of submicroscopy, visual diagnostics, and practical standards of statistical analysis of experimental data: parametric criteria of normal allocation of variance, standard deflexion of means. Results. EIA method fixed a lesion by the very virus of striatal mosaic of wheat VSMW of 7 specimens of winter wheat and of 1 of spring solid wheat. It is proved that Kharkov isolate of VSMW is analogous to the earlier described isolate of Poltava. It is determined that contamination of VSMW through seed grain is negligible and does not play essential role in epidemiology of this virus of wheat in Ukraine. Conclusions. It is proved that plants are affected with VSMW. The virus of striatal mosaic of wheat is identified by method of enzyme immunoassay. It is fixed that in conditions of Ukraine VSMW is transmitted by vectors - mites and mechanically, and by seed grain it is not spread.

Key words: virus of striatal mosaic of wheat (VSMW), hexapods-transmitting agents, enzyme immunoassay, submicroscopy, earstem grasses, winter wheat.

For stable gross grain harvest in Ukraine important presence of winter wheat with high adaptive capacity to adverse environmental factors. In cultures yield negative impact along with abiotic factors, many biotic factors such as fungi, bacteria, viruses [1-4].

We know that even under favorable conditions for crop yield losses of wheat viral diseases may be as high as $60 \%$ in some cases - $100 \%[5,6]$. Pathogens of viral etiology cause significant deterioration of grain quality by reducing the protein content and gluten in it [7].

At present, the most widespread in crops of grain crops, including winter wheat, on the territory of Ukraine (Wheat streak mosaic virus, WSMV) and viruses (Barley yellow dwarf virus, BYDV) [1, 3, 8, 9]. Much less common mosaic virus Kostroma, Bromus inermis mosaic wheat mosaic virus, "Russian Mosaic" [3].

In the Kharkiv region, until recently, the weather in September-October limiting mass distribution phyto viruses even during upswings number of carriers. On winter wheat in the north-eastern region was made possible due to a warming climate, prevailing weather conditions are extremely favorable for long-term supply of carriers on the stairs winter and spread of viral infection. 
Mass outbreaks of viral diseases most likely in years with high rainfall in May and June (contributes to the accumulation of viruses in dense herbage plants and resettlement of insect vectors), drought in August and September, causing obtain uneven stairs winter varying density and timing, increase migration vectors, and the warm sunny weather in September and October, provides long-term supply of insects on the stairs and a large number of infected plants [10].

For example, the spread of viral diseases in winter wheat in the Kharkiv region in 2006 was due to focus on its territory large areas of crops, and abnormally warm weather autumn period, which coincided in time with the next cyclical rise of the number of aphids and leafhoppers - carriers of phytovirus [1].

Striped wheat mosaic is typical of naturally-cell disease - a mandatory element in the circulation of the virus is the presence of intermediate plants scored among wild vegetation. Intensive destruction of crops striped mosaic matches the mass reproduction of mites (Aceria tritici Shevch.).

At infestation of winter wheat plants have a significant impact predecessors and sowing, phytosanitary against the best in the precursors is black couples peas and perennial legumes compared to stubble or corn.

In the early and especially very early sowing, wheat prevalence is significantly higher than the optimal or later. In some years with prolonged warm autumn when conditions are favorable for reproduction and distribution of mites, strong defeat disease and possible for sowing in optimal terms.

Harmful wheat streak mosaic during epiphytotic is economically feasible. Defeat plant causes reduction in the number of productive stems, grains in the ears, weight 1000 grains and reduced seed germination. Crop losses may reach $60-70 \%$ infestation of plants $-50-100 \%$. The degree of hazard depends on the timing of the virus infection - winter wheat is the most susceptible to the virus in the early phase of development. [11]

The main way of spreading WSMV - vectors mites Aceria. Also, the virus is transmitted mechanically and seeds, but the percentage of pathogen transmission by these routes is low, there are only a few foreign posts [12]. Marked fact infected wheat in New Zealand, where the mite Aceria tosichella not detected, indicating the effectiveness of seed transmission [12]. Recent studies suggest that the interaction between virus isolates and populations of vectors affecting the epidemiology of WSMV [13]. Thus, the purpose of our research was to determine the dominant species of pathogens of viral diseases of cereals in eastern steppes of Ukraine.

\section{Materials and methods.}

Virological monitoring conducted on wheat crops in eastern steppes of Ukraine in Kharkiv region in the fields of the Institute of Plant Jurjeva of HAAN in June 2015. Selected samples of plants showing symptoms of visually similar to those caused by viral infection, namely four samples of spring barley, spring wheat four samples (2 mild, 2 - solid) and 13 samples of winter wheat.

The identification of different types of viruses, was carried out using solid phase ELISA (sandwich version) using commercial test systems firm LOEWE (Germany). Results for reader reactions recorded Termo Labsystems Opsis MR (USA) with software Dynex Revelation Quicklink at wavelengths of 405/630 nm.

By taking significant value that exceeded the negative control three times [14]. Electron microscopic study of the morphology of viral particles was performed by transmission electron microscopy (EM) [15], using as kontrastera $2 \%$ phosphotungstic acid (CRF). Preparations accessed in the field of electron microscope JEM1400 (JEOL, Japan). Statistical analysis of experimental data was performed by parametric criteria of normal distribution option, the standard deviation of the mean values - with the conventional method.

\section{Results and discussion.}

The aim of our research was to determine the dominant species of pathogens of viral diseases of cereals in the eastern steppes of Ukraine and transmission of the virus. The results of inspections of crops winter wheat, spring barley and spring set individual plants with symptoms of viral diseases, such as light green and yellow strips of different lengths, extending parallel to a vein and a characteristic (Fig. 1. a, b, c, d) . 


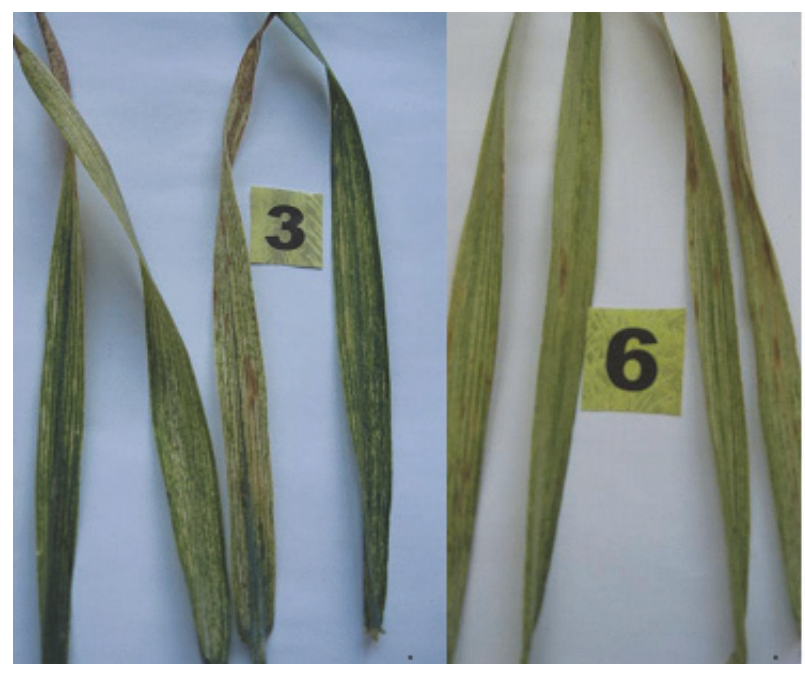

a

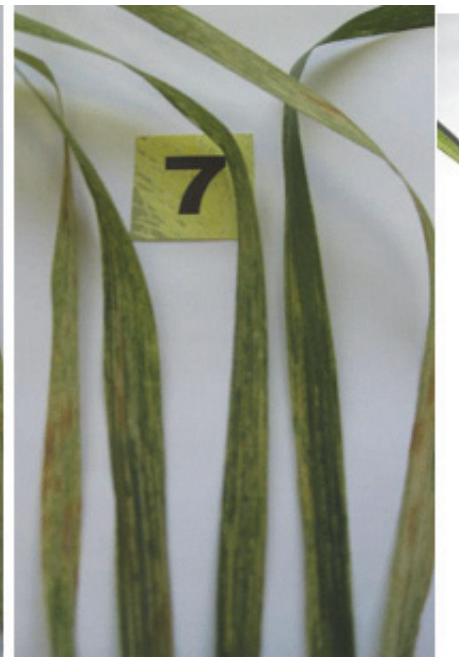

C

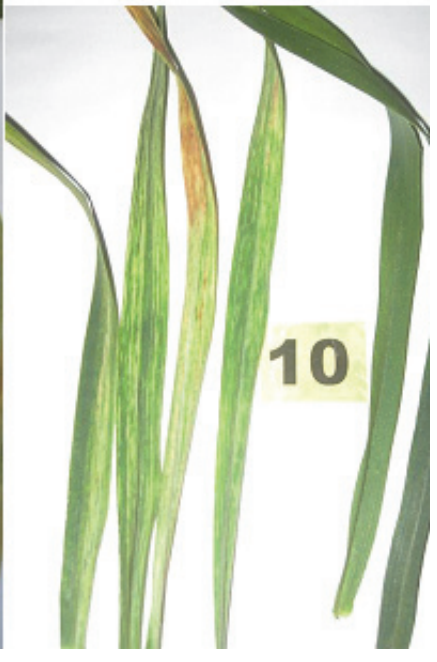

d

Fig. 1. Rash Symptoms on the leaves of winter wheat: a - sample number 3;

b-sample number 6; c-sample number 7, d-sample number 10

ELISA virus is found lesions streak mosaic Wheat (WSMV) of seven samples of winter wheat and spring wheat a solid (Fig. 2).

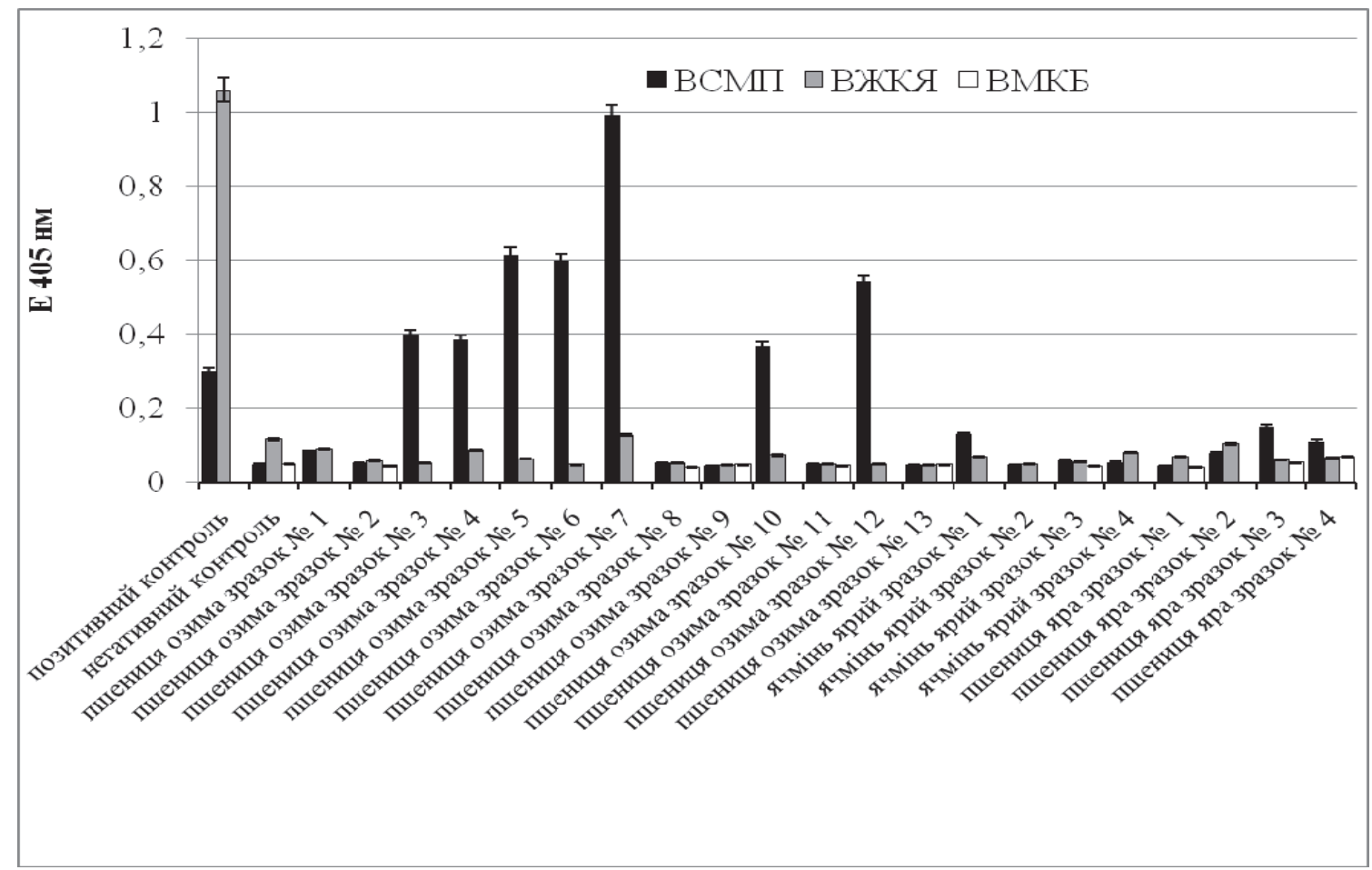

Fig. 2. The content of antigens in samples of wheat and barley

VZHKYA and VMKB antigens in tested samples are not detected. The method of transmission electron microscopy detected in leaves of winter wheat filamentous virus particles size of $770 \times 14 \mathrm{~nm}$ (Fig. 3). These two methods of virological prove exactly detected viral disease. Symptoms of disease identified as responsible in 
respect of Poltava previously described WSMV isolate [3]. In Kharkiv isolate WSMV we also observed a light green spots and strokes, which later become the yellow stripes that extend parallel to a vein

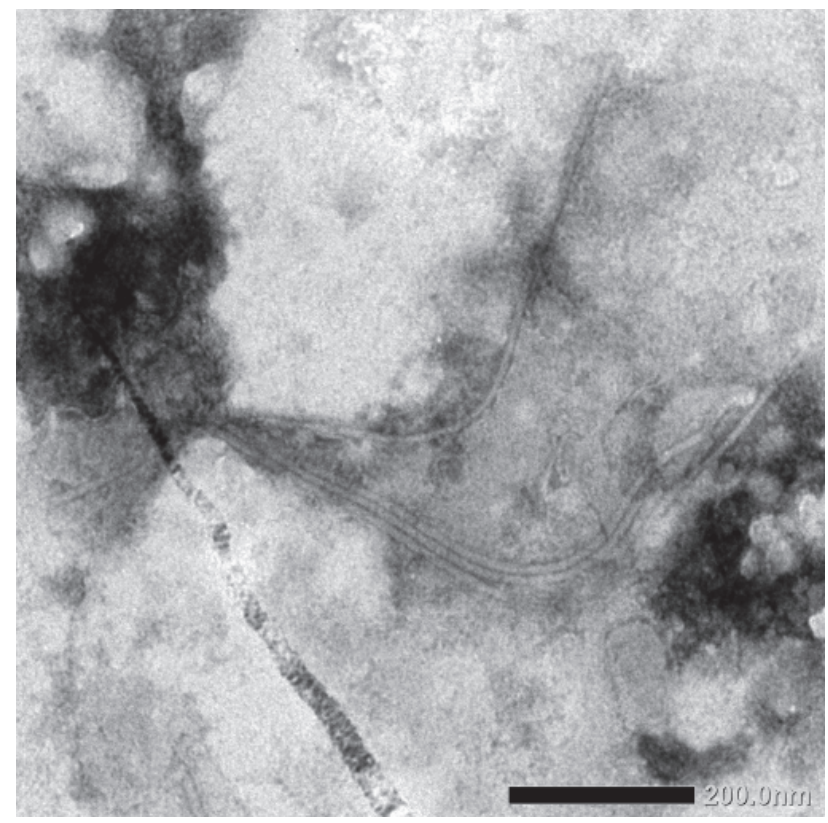

Fig. 3. Electron virions WSMV found in leaves of winter wheat (sample \# 7) under local agro-ecological monitoring Kharkiv region., June, 2015 (JEM-1400 with the prefix).

When the development of the disease harboring strip surface all leaf hlorotychnist covers almost the entire leaf plate (Fig. 1 b, 2 nd and 4 th leaf; Fig. 1 at 1 and 5 piece) appear nekrozni strips. With aging chlorotic leaf strips merge and become like parchment, and eventually it becomes light brown and wither. This is phase out the tube and heading, ie phases of active photosynthetic processes.

Analysis of the results indicates that, according to (morphological features of the detected virus WSMV, ELISA and showed its symptoms, the virus isolate Kharkiv wheat streak mosaic similar to described previously in Poltava region.

It is worth noting that more affected by viral diseases, including WSMV, samples of winter wheat, unlike spring Kolosov. This is due to a longer growing season and sometimes the power of culture on her insect vectors of disease. On plants affected by the fall, the symptoms are more obvious.

The problem of creating varieties resistant to pathogens of viral etiology that can reduce yield and quality, as spring and winter crops, now is certainly relevant.

One of the most important parts is to establish diagnosis fitovirusiv pathogen transmission. We know that WSMV transmitted mechanical inoculation and vectors, and as to spread its seeds - these are contradictory. Yes, Razvyazkina (1975) [16], Oleinik (1968) [17] argued that WSMV is not transmitted by seeds. Later in the scientific literature, there were reports of WSMV extending from the seed that caused the epidemic prevalence of the disease $[18,19,20]$. These data, as some scientists need to view the issue of Epidemiology streak mosaic virus and its spread wheat with sowing material and material genetics bank [21].

Given the subject of some scientists to confirm the presence of infection this way we conducted special studies in natural agrocenoses and controlled conditions described earlier on Poltava isolate WSMV [3]. To do this, the infected seed winter wheat varieties were seeded on 67 Myronivska research areas and under laboratory conditions (greenhouse) and examined by ELISA and EM. However, in no case WSMV antigens were detected (Table. 1). 
Table 1 - Study the possibility of transmission through WSMV seed

\begin{tabular}{|c|c|}
\hline Variant & The optical density, \\
& $E$ 405/630 HM \\
\hline negative control & $0,028 \pm 0,010$ \\
\hline positive control WSMV- infected wheat plants & $0,423 \pm 0,010$ \\
\hline \multicolumn{2}{|c|}{ Wheat plants new reproduction } \\
\hline Seed & $0,726 \pm 0,013$ \\
\hline Leaves & $0,029 \pm 0,012$ \\
\hline Grain of new crop & $0,044 \pm 0,010$ \\
\hline
\end{tabular}

It is established that corn and wheat leaves new reproduction WSMV contain antigens, and therefore the seed virus is not transmitted. If contamination through seed and WSMV possible, the frequency of such cases is negligible, and, we believe, does not play an important role in the epidemiology of the virus of wheat in Ukraine.

Electron microscopy and ELISA confirmed the absence of visual symptoms WSMV on wheat plants (Fig. 4).

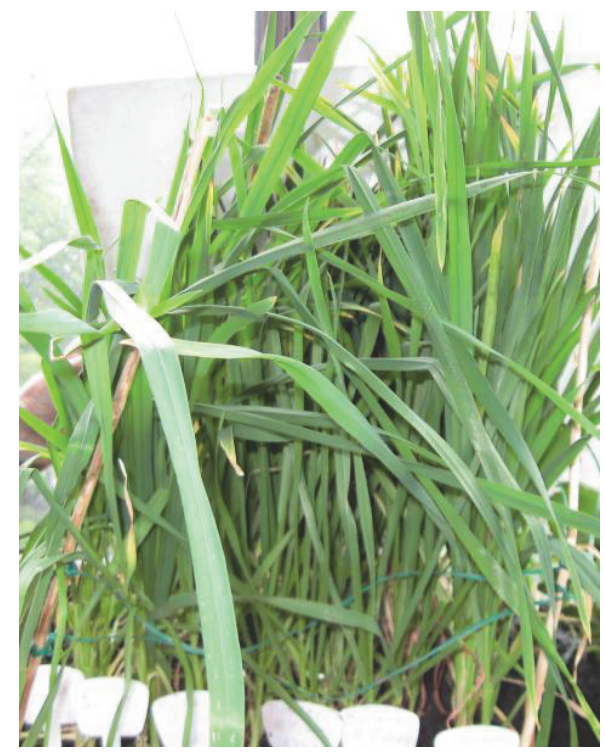

Fig. 4. Wheat Myronivska 67 grown from seed WSMV-infected plants field

Thus, the results of monitoring inspections of crops winter wheat, spring wheat and barley in the Kharkiv region the dominant species fitovirusiv. It is proved that plants infestation caused by a virus streak mosaic Wheat (WSMV). WSMV Diagnosis was confirmed by ELISA.

Symptoms lesions winter wheat streak mosaic virus similar to those that previously observed in many areas $[1,3,4,22]$. Confirmed that it circulates in zernosiyuchyh all regions of our country. The work towards the study of transmission of the virus and found that the latter in terms of Ukraine passed the vectors ticks and mechanically, and the seeds are not covered. In the future scheduled molecular phylogenetic studies and Kharkiv isolate the virus.

\section{Bibliography}

1. Petrenkova V.P. The problem of viral diseases of winter wheat in the Eastern Forest-steppe of Ukraine and directions of its solution / V.P. Petrenkova, I.M. Chernyayeva, N. I. Ryabchun, T. Yu. Markova. The Bulletin of Agrarian Science. - 2008. - No. 4. - P. 32-36. 
2. Yukhimenko A.I. Defeat of winter wheat with "yellow dwarf virus" of barley depending on meteorological conditions of vegetation / A.I. Yukhymenko, S.I. Voloshchuk, V.S. Korchmarsky // Collection of scientific works of the National Scientific Center "Institute of Agriculture of UAAS" . - 2008. - Special Issue. - P. 107-111.

3. Mischenko L.T. Viral diseases of winter wheat. - K.: Phytocenter. $-2009-352$ pp.

4. Rechetnik G.V. Diagnosis of viral infections of wheat under the influence of abiotic factors. - // Author's abstract. dis ... Candidate biology Sciences: special 03.00.06 "Virology", - K.: - 2010. - 22 p.

5. Velandia M., Rejesus R.M., Jones D.C. , Price J.A., Workneh F., M. Rush C.M. Economic impact of Wheat streak mosaic virus in the Texas High Plains // Crop Protection. - 2010. - Vol. 29. - P. 699-703.

7. Hadi B. A. R., Langhm M. A. C., Osborne L., J. Tilmon K. Wheat streak mosaic virus on wheat: biology and management //Journal of Integrated Pest Management. - 2011. - Vol. 2, no. 1. - P. J1-J5.

8. Boyko A.L., Mishchenko L.T., Baryshevsky A.N. etc. Recommendations on diagnostics of virus diseases of winter wheat and measures to control them in the conditions of the USSR. - K.: Harvest, 1990. $-25 \mathrm{p}$.

9. Gulyaeva I.I. Influence of the timing of winter cereal crop sowing on viruses /I.I. Gulyaeva // Agrarian Bulletin of the Black Sea Region. Agricultural and biological sciences. - 2010. \#.50. - P. 44-48

10. Mischenko L.T., Antipov O.I., Dunich AA, Grinchuk K.V. Striped mosaic of wheat and yellow dwarf barley in the Forest-Steppe and Steppe Ukraine // Quarantine and plant protection. - 2014. \# 2. - P. 4-8.

11. Prevention of loss of winter wheat crops from viral diseases and their carriers in the South of the USSR. Methodical recommendations. - Sost. MP Nikolenko, L.I. Omelchenko. - Odessa, 1985. - P. 13-27.

12. Markova T. Yu. Wheat mite (Aceria tritici) - a dangerous vector of the virus of striped mosaic of wheat / T.Yu. Markov, I.M. Chernyayev, V.P. Petrenkova / Agronomist. - No. 1 - 2013. - P. 84-85.

13. Lebas B. S. M., F. M. Ochoa-Corona, and B. J. R. Alexander, R. A. Lister, J. D. F.Fletcher, S. L. Bithell, Burnip G. M. First Report of Wheat streak mosaic virus on Wheat in New Zealand // Plant disease. 2009. - Vol. 93, \# 4. P. 430.

14. Wosula E. N. , A. J. McMechan, C. Oliveira-Hofman ,S. N. Wegulo, Hein G. L. Differential Transmission of Two Isolates of Wheat streak mosaic virus by Five Wheat Curl Mite Populations // Plant disease. - 2016. Vol. 100, \#1. - P. 154-158.

15. Clark M. F., Adams A. N. Characteristics of the microplate method of enzyme-linked immunosorbent assay for the detection of plant viruses // J. Gen. Virology. - 1977. - Vol. 34. - P. 574- 586.

16. Dijkstra J. Practical Plant Virology: Protocols And Exercises / J. Dijkstra, Cees P. de Jager. - Berlin: Springer.Verlag and Heidelberg GmbH \& Co, 1998. - 459 p.

17. Razvyazkina G. M. Viral diseases of cereals / G. M. Rvyyazkina. Novosibirsk: Science, 1975. - 291 pp.

18. Oleynik A.N. Striped mosaic of wheat in Ukraine: author's abstract. dis ... Candidate biol. Sciences: special 03.00.06 "Virology" / A.N. Oleynyk. - K.:, 1968. - 15 p.

19. Rabenstein F. Phylogenetic relationships, strain diversity and biogeography of tritimoviruses / F. Rabenstein, D. L. Seifers, J. Schubert [et al.] // J. Gen. Virol. - 2002. - Vol. 83. - P. 895-906.

20. Jones R. A. C. Seed transmission of Wheat streak mosaic virus shown unequivocally in wheat / R. A. C. Jones, B. A. Coutts, A. E. Mackie, G. I. Dwyer // Plant Dis. - 2005. - Vol. 89. - P. 1048-1050.

21. Dwyer et al., Wheat streak mosaic virus in Australia: Relationship to isolates from the Pacific Northwest of the USA and its dispersion via seed transmission / G. L. Dwyer, M. J. Gibbs, A. J. Gibbs [et al.] // Plant Disease. - 2007.- Vol. 91. - P. 164-170.

22. Sharpard D., Ordon F., Rabenstein F., et al. Economic significance, distribution and control of viruses of cereals and fodder crops tolerated by ticks and insects in Germany // Herald of plant protection. St. Petersburg. - 2008. - №1. - P. 14-26.

23. Shevchenko Zh.P. Viral and mycoplasma diseases of cereal colic. - K.: Urozhay, 1995. - 71 p. 